\title{
Biphasic ATP Depletion Caused by Transient Oxidative Exposure Is Associated with Apoptotic Cell Death in Rat Embryonal Cortical Neurons
}

\author{
HENRIKKA AITO, KRISTIINA T. AALTO, AND KARI O. RAIVIO \\ Hospital for Children and Adolescents, FIN-00029 HUS, Helsinki, Finland
}

\begin{abstract}
Hypoxia-ischemia leads to an acute depletion of high-energy phosphates in neonatal brain. After reperfusion, energy status is restored, but may show progressive secondary failure, associated with neuronal loss, brain damage, or death. Oxidants are produced on reperfusion. We investigated whether a biphasic energy failure develops in cultured neurons after oxidant exposure, and whether the degree of primary disturbance correlates with later ATP synthesis and mode of cell death. Embryonic rat cortical neurons were exposed to varying doses of hydrogen peroxide for $60 \mathrm{~min}$ and incubated for 12,24 , or $48 \mathrm{~h}$. Adenine nucleotides and the incorporation of $\left[{ }^{14} \mathrm{C}\right]$ adenine into adenine nucleotides were quantified. Apoptosis was evaluated by DNA electrophoresis and in situ end-labeling. A mild insult (10-50 $\mu \mathrm{M})$ caused no ATP depletion or change in subsequent growth or energy metabolism, whereas an intermediate insult $(100 \mu \mathrm{M})$ caused acute ATP depletion ( $49 \pm 12 \%$ of control). This recovered to $91 \pm$ $28 \%$ by $12 \mathrm{~h}$, but then declined to $61 \pm 18 \%$ at $24 \mathrm{~h}$. A severe insult $(1 \mathrm{mM})$ depleted ATP to $15 \pm 3 \%$ of control, with no
\end{abstract}

\section{ABSTRACT}

recovery. Moderate ATP depletion was associated with apoptotic cell death, whereas a severe insult caused acute necrosis. Transient oxidant exposure of embryonal cortical neurons causes a biphasic energy depletion followed by apoptosis in analogy with asphyxiated brains. This model may prove useful for the study of pathogenesis and treatment of hypoxic-ischemic encephalopathy. (Pediatr Res 52: 40-45, 2002)

$\quad$ Abbreviations
ANs, adenine nucleotides
DIG-ddUTP, digoxigenin-11-ddUTP
EC, energy charge
$\mathbf{H}_{\mathbf{2}} \mathbf{O}_{\mathbf{2}}$, hydrogen peroxide
ISEL, in situ end-labeling
PARP, poly(ADP ribose) polymerase
PCr, phosphocreatine
$\mathbf{P}_{\mathbf{i}}$, inorganic phosphate
TdT, terminal transferase

tion during the primary insult correlates with the number of apoptotic and necrotic cells in the brains of asphyxiated piglets

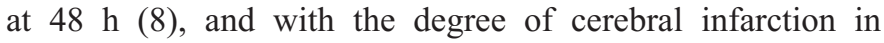
developing rats (6). In an immature rat model, the neuronal death caused by a short ischemic period may mostly be accounted for by apoptosis, whereas severe ischemia may produce immediate or delayed necrosis (9).

Acute disruption of oxidative phosphorylation during ischemia leads to loss of ion homeostasis, particularly a massive calcium influx, which has multiple effects on cellular functions. If long-lasting enough, ischemia produces immediate cell death. After a period of nonfatal cerebral ischemia, reperfusion is associated with increased mitochondrial or cytoplasmic generation of reactive oxygen metabolites, e.g. superoxide, which is converted to $\mathrm{H}_{2} \mathrm{O}_{2}$ by superoxide dismutases [reviewed by Fellman and Raivio (10)]. $\mathrm{H}_{2} \mathrm{O}_{2}$ is a freely diffusing oxidant, which in vitro triggers neuronal apoptosis (11), leading to acute and delayed ATP depletion (12).

Although it is known that in the absence of cellular ATP the apoptotic program can switch to necrosis (13-16), the correlation of the acute ATP depletion caused by an oxidative insult
Received March 19, 2001; accepted February 22, 2002

Correspondence and reprint requests: Henrikka Aito, M.D., Hospital for Children and Adolescents, P.O. Box 280, FIN-00029 HUS, Helsinki, Finland; e-mail: henrikka.aito@hus.fi

Supported by the Foundation for Pediatric Research (H.A., K.A.), and the Research Funds of Helsinki University Central Hospital, Finland (H.A.).

DOI: 10.1023/01.PDR.0000016665.07813.0B 
with later energy metabolism in cortical neurons has not been investigated. Therefore, the aim of this study was to test whether the initial disturbance in the balance of high-energy nucleotides caused by a transient oxidative insult is reversible and whether its severity would predict later ATP synthesis and subsequent mode of cell death in vitro. A biphasic disturbance in energy metabolism would correlate with that observed in the brains of asphyxiated human infants and neonatal animals, providing a reproducible model for studying some components of hypoxic-ischemic neuronal injury.

\section{METHODS}

Cell culture. Cells from cerebral hemispheres of 18-d-old rat embryos were prepared as previously described (17). Freshly prepared neurons in Dulbecco's modified Eagle's medium (DMEM, GIBCO Europe, Paisley, U. K.), supplemented with $10 \%$ fetal bovine serum and containing penicillin-streptomycin $(100 \mathrm{IU} / \mathrm{mL}$ and $50 \mu \mathrm{g} / \mathrm{mL})$, were plated on poly-L-lysinecoated four-well culture dishes (Nunc, Roskilde, Denmark) or 50-mm Petri dishes (Nunc) at a controlled density averaging 750 cells $/ \mathrm{mm}^{2}$ and incubated in $95 \%$ air $/ 5 \% \mathrm{CO}_{2}$ at $37^{\circ} \mathrm{C}$ in a humidified incubator. The next day the culture medium was changed to serum-free Neurobasal medium supplemented with B27 (GIBCO), and replaced after $4 \mathrm{~d}$. These cells have been previously characterized and shown to be mainly (80-90\%) neurons (17). This primary cell culture system has been approved by the Ethical Board of the University of Helsinki.

Oxidant exposure. On d 5-7, when the cells were showing marked neuronal outgrowth, the medium was replaced with serum-free DMEM containing freshly prepared $\mathrm{H}_{2} \mathrm{O}_{2}$ at a final concentration of $0 \mu \mathrm{M}, 10 \mu \mathrm{M}, 50 \mu \mathrm{M}, 100 \mu \mathrm{M}, 1 \mathrm{mM}$, or 5 $\mathrm{mM}$ (Merck AG, Darmstadt, Germany) and incubated at $37^{\circ} \mathrm{C}$ for $60 \mathrm{~min}$. The $\mathrm{H}_{2} \mathrm{O}_{2}$ concentrations were verified by spectrophotometric analysis at $240 \mathrm{~nm}$, using the molar extinction coefficient of $44 \mathrm{M}^{-1} \cdot \mathrm{cm}^{-1}$ for $\mathrm{H}_{2} \mathrm{O}_{2}$. Control cells were treated equally but with omission of $\mathrm{H}_{2} \mathrm{O}_{2}$.

After exposure, the cells were either collected immediately for analysis or incubated further in defined culture medium (Neurobasal + B27) for 12, 24, or $48 \mathrm{~h}$, and then analyzed. For DNA analysis, the experiments were performed on Petri dishes.

Analysis of DNA degradation. The exposed cells as well as their unexposed controls were scraped into medium, pelleted, resuspended in $200 \mu \mathrm{L}$ of PBS, and quickly frozen in liquid nitrogen. DNA was extracted using the Apoptotic DNA ladder kit (Roche Biochemicals, Basel, Switzerland), quantified, and electrophoresed $(3 \mu \mathrm{g} / \mathrm{lane}, 50 \mathrm{~V}, 3.5 \mathrm{~h})$ on $2 \%$ standard low-melting agarose gel, then visualized with a fluorescent DNA-binding dye SYBR Gold (Molecular Probes Europe, Leiden, The Netherlands) and photographed under UV illumination.

ISEL of DNA. The neurons were plated on poly-L-lysinecoated round glass coverslips on four-well culture dishes (Nunc) and grown as described earlier. They were then exposed to indicated concentrations of $\mathrm{H}_{2} \mathrm{O}_{2}$ for $60 \mathrm{~min}$, incubated in defined culture medium for $24 \mathrm{~h}$, washed twice, and fixed in $4 \%$ paraformaldehyde. The cells were permeabilized in ice-cold mixture of ethanol and acetic acid (2:1), and after washing, placed in a microwave oven for $5 \mathrm{~min}$ in $10 \mathrm{mM}$ citric acid (pH 6.0). After washing, the cells were preincubated with terminal transferase reaction buffer (potassium cacodylate, 1 $\mathrm{M}$; Tris-HCl, $125 \mathrm{mM}$; BSA, $1.25 \mathrm{mg} / \mathrm{mL} ; \mathrm{pH}$ 6.6). The apoptotic DNA fragments were 3'-end-labeled with DIGddUTP (Roche Diagnostics, Mannheim, Germany) by the TdT (Roche Diagnostics) reaction for $1 \mathrm{~h}$ at $37^{\circ} \mathrm{C}$. Antidigoxigenin antibody conjugated to horseradish peroxidase (1:50, Roche Diagnostics) and diaminobenzidine (Sigma Chemical Co., St. Louis, MO, U.S.A.) were used to detect DIG-ddUTP-labeled DNA. For the negative controls, the TdT enzyme was replaced by the same volume of distilled water. The coverslips were then dehydrated, mounted, and photographed under a light microscope $(\times 40$, interference contrast).

AN depletion assay. Before the exposure, cells were prelabeled overnight with $\left[{ }^{14} \mathrm{C}\right]$ adenine (final concentration, 100 $\mu \mathrm{M}$; specific activity, $287 \mathrm{mCi} / \mathrm{mmol}$; Amersham Pharmacia Biotech UK, Ltd., Little Chalfont, Buckinghamshire, U.K.) in defined culture medium. The labeled medium was then removed, and cells were exposed as appropriate. Directly after exposure, the medium was removed, and the cellular ANs were extracted on ice with perchloric acid. ATP, ADP, and AMP were separated by thin-layer chromatography, and the radioactivities in the ANs, which correspond to their intracellular concentrations, were measured with a liquid scintillation counter (Rackbeta 1209, LKB Wallac, Turku, Finland) (18). The adenylate EC, defined as $[([\mathrm{ATP}]+1 / 2[\mathrm{ADP}]) /([\mathrm{ATP}]+$ $[\mathrm{ADP}]+[\mathrm{AMP}])]$, was used as a measure of cellular metabolic integrity (19).

Labeling of the AN pool. To measure the incorporation of $\left[{ }^{14} \mathrm{C}\right]$ adenine into cellular nucleotides after an oxidant exposure, the culture medium of exposed as well as unexposed control cultures was supplemented with $\left[{ }^{14} \mathrm{C}\right]$ adenine (final concentration $100 \mu \mathrm{M})$. After further incubation for 12 or $24 \mathrm{~h}$, the cellular ANs were extracted with perchloric acid on ice and quantified (18).

Analysis of ANs by HPLC. ATP, ADP, and AMP concentrations in the neutralized perchloric acid extracts were measured using a Shimadzu LC 10AD vp liquid chromatograph with a reversed-phase column (Ultra Techsphere 5 ODS, Labtronic Oy, Vantaa, Finland) and a UV detector set at 254 $\mathrm{nm}$. The published method (20) was modified as follows: buffer A $\left(0.1 \mathrm{M} \mathrm{KH}_{2} \mathrm{PO}_{4}, 8.0 \mathrm{mM}\right.$ tetrabutylammonium hydrogen sulfate, $\mathrm{pH} 6.0$ ) was run at $1.5 \mathrm{~mL} / \mathrm{min}$ for $2.5 \mathrm{~min}$ followed by a linear increase for $10 \mathrm{~min}$ to $100 \%$ buffer B (buffer A with $30 \%$ methanol), which was continued for $5 \mathrm{~min}$. Compounds were identified and quantified by the retention times and peak areas of known standards, calibrated by spectrophotometry.

Protein analysis. Cells from parallel cocultures were homogenized in potassium phosphate buffer, and their protein content was determined by spectrophotometry using the BioRad DC kit (Bio-Rad, Hercules, CA, U.S.A.).

Data analysis. Results are expressed as mean \pm SD of two to four independent experiments performed at least in duplicate, each with its own control. The statistical group comparisons were made among control and test conditions by ANOVA combined with Bonferroni post hoc test (SPSS 10.0 
Software for Windows, SPSS, Chicago, IL, U.S.A.). A $p<$ 0.05 was considered significant. For illustration, the data are also shown as percent of control.

\section{RESULTS}

Cell and DNA damage. When examined after $24 \mathrm{~h}$, the cells exposed for $60 \mathrm{~min}$ to $10-50 \mu \mathrm{M}$ of $\mathrm{H}_{2} \mathrm{O}_{2}$ did not differ morphologically from control cells showing intact neurites and
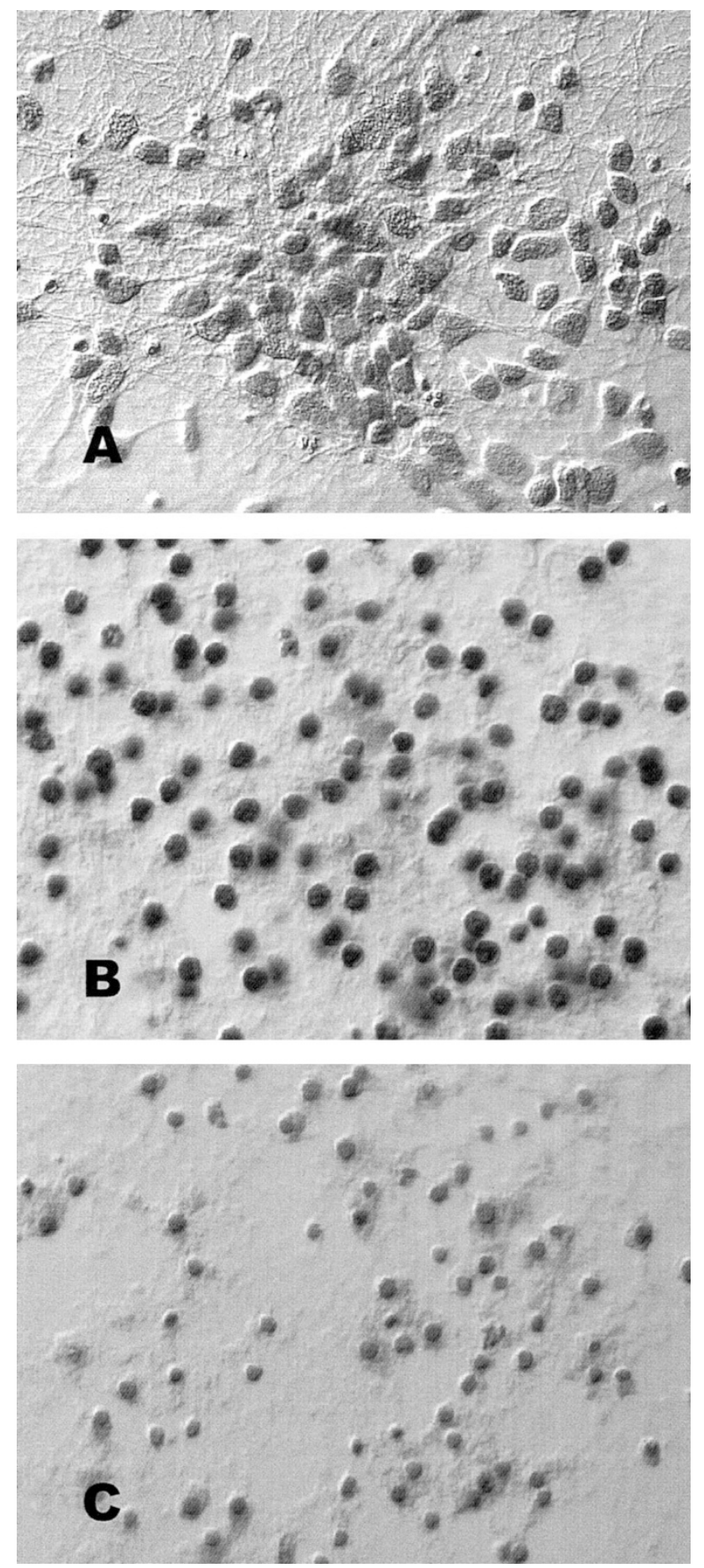

Figure 1. ISEL staining of fragmented DNA. Control cells at $24 \mathrm{~h}(A)$ and after a 60 -min exposure to $100 \mu \mathrm{M}(B)$ or $1 \mathrm{mM}(C)$ of $\mathrm{H}_{2} \mathrm{O}_{2}$ and additional 24-h incubation. Light microscopy $(\times 40$, interference contrast). only light staining by ISEL (Fig. 1A), whereas cells exposed to $100 \mu \mathrm{M} \mathrm{H}_{2} \mathrm{O}_{2}$ were round and pyknotic and showed uniform ISEL (Fig. $1 B$ ). Cells exposed to a higher concentration of $\mathrm{H}_{2} \mathrm{O}_{2}(1 \mathrm{mM})$ formed a necrotic mass with distorted cell outlines at $24 \mathrm{~h}$, but ISEL showed a scanty pattern of nuclear staining (Fig. 1C).

At $24 \mathrm{~h}$, the yields of extracted DNA from plates exposed to $100 \mu \mathrm{M}$ and $1 \mathrm{mM} \mathrm{H}_{2} \mathrm{O}_{2}$ for 60 min were significantly lower than those from unexposed control cells $(18.7 \pm 3.0 \mu \mathrm{g}$ and $13.4 \pm 3.4 \mu \mathrm{g}$ versus $39.0 \pm 14.3 \mu \mathrm{g}$ per plate, respectively, $p=0.03$ versus control), indicating a corresponding loss of cells. The yield of extracted DNA of cells exposed to 10-50 $\mu \mathrm{M} \mathrm{H}_{2} \mathrm{O}_{2}$ did not differ statistically from that of the unexposed control cells. These cells showed a DNA electrophoresis pattern (Fig. 2, lane 2) no different from that of the control cells at $24 \mathrm{~h}$ (Fig. 2, lane 1). After exposure to the intermediate concentration of $\mathrm{H}_{2} \mathrm{O}_{2}(100 \mu \mathrm{M})$, the extracted DNA was visualized as a ladder pattern suggestive of apoptosis (Fig. 2, lane 3). Exposure to higher (1-5 mM) concentrations of $\mathrm{H}_{2} \mathrm{O}_{2}$ resulted in smearing of the DNA (Fig. 2, lane 4). However, occasionally a ladder was detected (Fig. 2, lane 5), possibly representing fragmented DNA of residual apoptotic cells, whereas totally degraded DNA of necrotic cells would not be seen in electrophoresis or in DNA assay.

Acute AN depletion. Exposure to $\mathrm{H}_{2} \mathrm{O}_{2}$ for 60 min caused an acute dose-dependent reduction in radioactivity in total cellular ANs (Fig. 3). This depletion was accompanied by a corresponding increase of catabolic products in the culture medium,

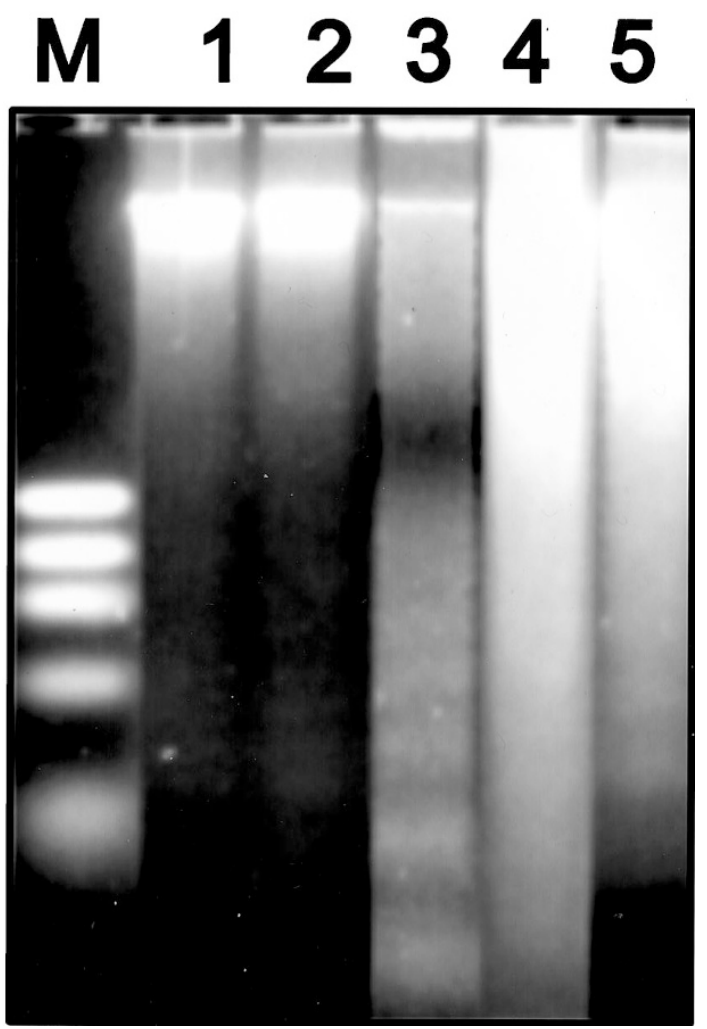

Figure 2. Fragmentation of DNA in neurons exposed for $60 \mathrm{~min}$ to the indicated concentrations of $\mathrm{H}_{2} \mathrm{O}_{2}$. DNA was extracted after an additional $24 \mathrm{~h}$ culture and separated by agarose gel electrophoresis. See text for details. Lane 1, control cells; lane 2, $10 \mu \mathrm{M}$; lane 3, $100 \mu \mathrm{M}$; lanes 4 and 5, $1 \mathrm{mM}$. 
an average of $85 \pm 2 \%$ of the radioactivity being in hypoxanthine. After low concentrations $(10-50 \mu \mathrm{M})$, the cellular ANs decreased slightly but significantly to $92.0 \pm 17.6 \%$ of control $(n=16, p<0.05)$. An exposure to $100 \mu \mathrm{M} \mathrm{H}_{2} \mathrm{O}_{2}$ depleted cellular ANs to $48.6 \pm 11.6 \%(p<0.001$ versus control, $n=$ 14). The highest concentration of $\mathrm{H}_{2} \mathrm{O}_{2}$ tested $(5 \mathrm{mM})$ caused a maximum AN depletion to $15.6 \pm 6.2 \%$ of control values ( $p$ $<0.001$ versus control and versus $1 \mathrm{mM}$ exposure, $n=10$ ).

Reduction in radioactivity of cellular ATP after a 60-min exposure to $\mathrm{H}_{2} \mathrm{O}_{2}$ was more pronounced than that of total ANs at intermediate to high concentrations, reflecting a corresponding decrease in cellular EC (Fig. 3). Low concentrations of $\mathrm{H}_{2} \mathrm{O}_{2}(10-50 \mu \mathrm{M})$ induced no change in ATP content, but 100 $\mu \mathrm{M}$ caused an acute depletion to $39.5 \pm 11.8 \%(p<0.001, n$ $=12$ ), and $1 \mathrm{mM}$ to $14.8 \pm 3.1 \%$ of control values $(p<0.001$ versus control and versus $100 \mu \mathrm{M}$ exposure, $n=6$ ). At higher $\mathrm{H}_{2} \mathrm{O}_{2}$ concentrations $(5 \mathrm{mM})$, radioactivity in cellular ATP did not differ from blank values $(3.1 \pm 0.4 \%$ of control, $n=10)$.

Cellular EC. In prelabeled untreated control cell cultures, the EC, calculated from radioactivities in the separated ANs, averaged $0.83 \pm 0.08$. After exposure to low concentrations $(10-50 \mu \mathrm{M})$ of $\mathrm{H}_{2} \mathrm{O}_{2}$ for 60 min the EC was $1.0 \pm 0.07$, which was not significantly different from control. Higher concentrations of $\mathrm{H}_{2} \mathrm{O}_{2}$ caused a dose-dependent decrease in cellular EC, reaching $38.5 \pm 13.2 \%$ of control values at $5 \mathrm{mM} \mathrm{H}_{2} \mathrm{O}_{2}$ (Fig. 3).

Recovery and redepletion of AN levels. To assess the capacity of neurons to resynthesize and maintain their ANs after exposure to $\mathrm{H}_{2} \mathrm{O}_{2}$, the incorporation of $\left[{ }^{14} \mathrm{C}\right]$ adenine into ATP was measured as a function of time and $\mathrm{H}_{2} \mathrm{O}_{2}$ concentration. These data are shown in Figure 4, which also includes cellular ATP levels immediately after exposure. ATP synthesis after exposure to $10-50 \mu \mathrm{M}$ of $\mathrm{H}_{2} \mathrm{O}_{2}$ paralleled that of the untreated control cells, the radioactivity in cellular ATP being $92.6 \pm$ $25.2 \%$ and $112.8 \pm 14.9 \%$ of control cells at 12 and $24 \mathrm{~h}$, respectively (NS versus control cells, $n=12$ for $12 \mathrm{~h}$, and $n=$ 8 for $24 \mathrm{~h}$, respectively.)

After exposure to $100 \mu \mathrm{M} \mathrm{H}_{2} \mathrm{O}_{2}$, which caused significant acute ATP depletion, the radioactivity in ATP recovered to $91.2 \pm 28.0 \%$ at $12 \mathrm{~h}$ (NS versus control, $n=12$ ), but showed

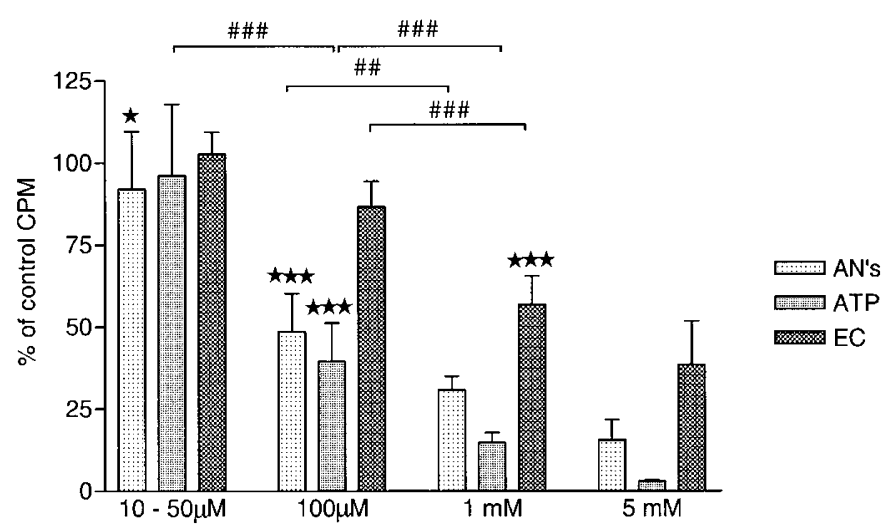

Figure 3. Cellular ANs, ATP, and EC at the end of a 60-min exposure to indicated concentrations of $\mathrm{H}_{2} \mathrm{O}_{2}$ in prelabeled cells as $\% \pm \mathrm{SD}$ of control cpm. ${ }^{*} p<0.05,{ }^{* *} p<0.01$, and ${ }^{* * *} p<0.001$ vs control; \#\#p $<0.01$ and $\# \# p<0.001$ vs differing concentrations. See text for details.

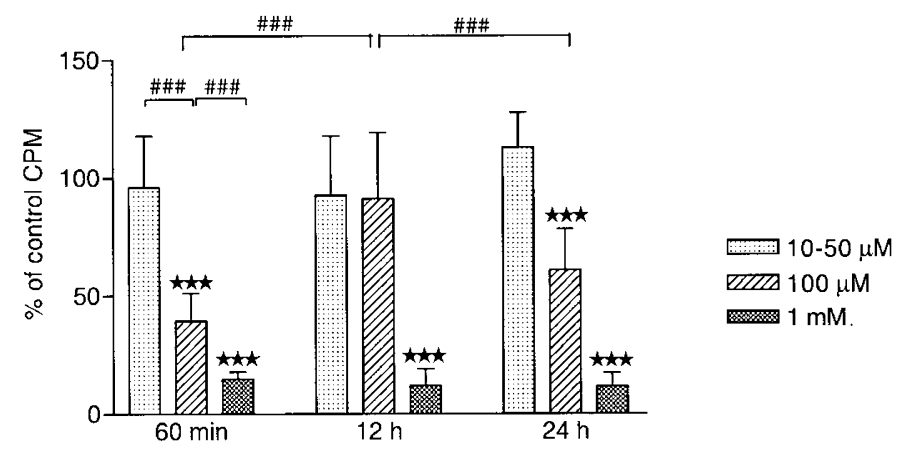

Figure 4. Cellular ATP in adenine-prelabeled cells at the end of a 60-min exposure to indicated concentrations of $\mathrm{H}_{2} \mathrm{O}_{2}(60 \mathrm{~min})$, and in cells labeled with $\left[{ }^{14} \mathrm{C}\right]$ adenine directly after exposure followed by an additional incubation for $12 \mathrm{~h}(12 \mathrm{~h}, n=12)$ or $24 \mathrm{~h}(24 \mathrm{~h}, n=8)$, expressed as $\% \pm \mathrm{SD}$ of control cpm. ${ }^{* * *} p<0.001$ vs control; \#\#p $<0.001$ and \#\#p $<0.01$ vs differing times or concentrations.

a secondary decline to $60.8 \pm 17.5 \%(p<0.001, n=12)$ of untreated control values at $24 \mathrm{~h}$ (Fig. 4). After exposure to 1 $\mathrm{mM} \mathrm{H}_{2} \mathrm{O}_{2}$, the radioactivity in ATP showed no recovery, remaining at $12.0 \pm 7.2 \%$ and $11.6 \pm 5.8 \%$ of control values, at 12 and $24 \mathrm{~h}$, respectively ( $p<0.001$ versus control and cells exposed to $100 \mu \mathrm{M}, n=10$ for $12 \mathrm{~h}$ and $n=8$ for $24 \mathrm{~h}$ ). Extending the incubation time to $48 \mathrm{~h}$ resulted in marked reduction in the uptake of $\left[{ }^{14} \mathrm{C}\right]$ adenine also in untreated control cells, but the absolute counts per minute of cells treated with $100 \mu \mathrm{M}$ of $\mathrm{H}_{2} \mathrm{O}_{2}$ continued to decline, and levels relative to control cells remained at the level of $24 \mathrm{~h}$ (data not shown). The incorporation of $\left[{ }^{14} \mathrm{C}\right]$ adenine into ATP was in the same proportion as into the other high-energy nucleotides, so that the cellular EC levels did not differ significantly from control levels $(0.92 \pm 0.02)$ during the 12 - to 24 -h follow-up period at any exposure level (data not shown). Also, the radioactivity in nucleotides recovered from the medium of the exposed cells, reflecting acute cell membrane injury, remained at control values at $24 \mathrm{~h}$ (data not shown).

The ATP concentrations measured by HPLC corresponded well with the incorporation of $\left[{ }^{14} \mathrm{C}\right]$ adenine into cellular highenergy nucleotides (Fig. 5). The cellular ATP content, normalized to protein, showed an acute reduction after treatment with $100 \mu \mathrm{M}$ of $\mathrm{H}_{2} \mathrm{O}_{2}$ for $60 \mathrm{~min}$, identical to that determined with the radioactive nucleotide depletion assay $(36.5 \pm 16.5 \%$ of

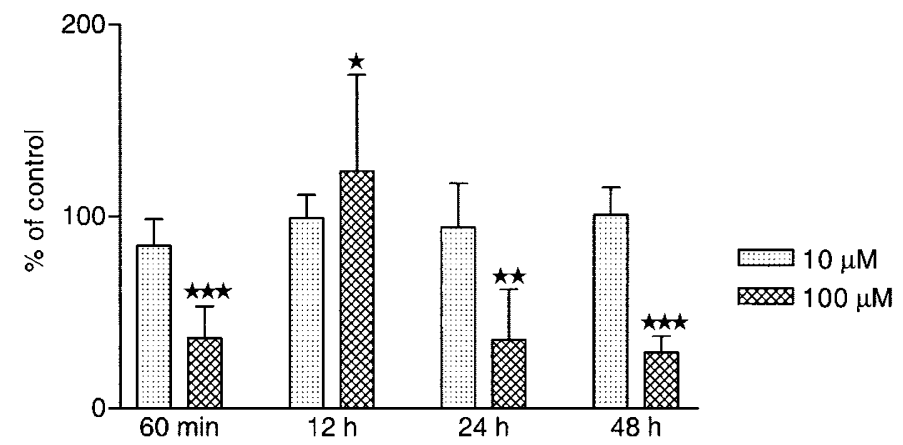

Figure 5. ATP concentration measured by HPLC and normalized to protein content as $\% \pm \mathrm{SD}$ of untreated control values at the end of a 60-min exposure to 10 or $100 \mu \mathrm{M} \mathrm{H}_{2} \mathrm{O}_{2}$ or after an additional incubation for $12 \mathrm{~h}(n=6), 24 \mathrm{~h}$ $(n=14)$, or $48 \mathrm{~h}(n=4) .{ }^{* * *} p<0.001$ vs untreated control cells. 
control, $n=6)$. At low exposure level $(10 \mu \mathrm{M})$, the ATP concentration remained at the control level up to $48 \mathrm{~h}(n=4)$. After the intermediate insult $\left(100 \mu \mathrm{M}\right.$ of $\left.\mathrm{H}_{2} \mathrm{O}_{2}\right)$, the acute ATP depletion recovered to $123.7 \pm 50.2 \%$ of control $(27.0 \pm 10.4$ $\mu \mathrm{mol}$ of ATP/mg of protein) by $12 \mathrm{~h}$. However, at $24 \mathrm{~h}$, the ATP concentration of these cells showed a secondary decline to $35.7 \pm 26.1 \%$ of control, $(7.3 \pm 4.6 \mu \mathrm{mol}$ of $\mathrm{ATP} / \mathrm{mg}$ of protein), which continued to $29.3 \pm 8.3 \%$ of control at $48 \mathrm{~h}$ $(0.61 \pm 0.2 \mu \mathrm{mol}$ of ATP $/ \mathrm{mg}$ of protein; Fig. 5). The ATP concentration of cells exposed to $1 \mathrm{mM} \mathrm{H}_{2} \mathrm{O}_{2}$ was less than the detection limit for the HPLC method at all times investigated.

\section{DISCUSSION}

We showed that $\mathrm{H}_{2} \mathrm{O}_{2}$ induces a dose-dependent reduction in cellular EC and ATP, which, after a moderate dose, temporarily recovers, but after $24 \mathrm{~h}$ shows a secondary reduction. This secondary depletion of cellular ATP is associated with apoptotic cell death. A mild insult causes no changes in energy metabolism or cell survival, whereas a large dose of $\mathrm{H}_{2} \mathrm{O}_{2}$ results in severe ATP depletion and necrotic cell death. Our model thus mimics the findings of in vivo studies in newborn animals, in which severe asphyxia followed by resuscitation produces a biphasic impairment in cerebral oxidative phosphorylation, followed by brain damage $(1,2)$.

Generation of reactive oxygen metabolites has been clearly documented in the reperfused brain of experimental animals (21-26). The role of oxidants in the pathogenesis of hypoxicischemic encephalopathy is supported by the reduction of organ damage in stroke models by antioxidant treatment (27) or by overexpression of mitochondrial superoxide dismutase $(28,29)$. Concentrations of $\mathrm{H}_{2} \mathrm{O}_{2}$ at the range of $100 \mu \mathrm{M}$ have been detected in vivo by microdialysis during the reperfusion period after $30 \mathrm{~min}$ of forebrain ischemia, which results in a substantial neuronal loss at $24 \mathrm{~h}(30)$. In vitro, $\mathrm{H}_{2} \mathrm{O}_{2}$ exposure is an effective inducer of neuronal apoptosis (11), associated with acute and delayed ATP depletion (12). In neuroectodermal cells, the severity of the acute ATP depletion caused by $\mathrm{H}_{2} \mathrm{O}_{2}$ correlates with later survival and apoptosis (31).

In the present model, concentrations of $\mathrm{H}_{2} \mathrm{O}_{2}$ in the range of $10-50 \mu \mathrm{M}$ had no or mild transient effects on neuronal ANs and caused no observable delayed damage to the cells. The primary antioxidant defense against $\mathrm{H}_{2} \mathrm{O}_{2}$ in brain is glutathione peroxidase (32), which may have adequate activity in these cultured neurons to cope with the oxidant at low concentrations. On the other hand, levels of $\mathrm{H}_{2} \mathrm{O}_{2}$ at or exceeding $1 \mathrm{mM}$ caused an irreversible energy failure and acute cell death, which had the microscopic characteristics of necrosis, although a small subpopulation of cells may have survived the initial insult and died by a delayed mechanism. The intermediate concentration of $100 \mu \mathrm{M} \mathrm{H} \mathrm{H}_{2} \mathrm{O}_{2}$ caused a moderate acute depletion of ATP (to approximately $40 \%$ of control), which recovered to control levels at $12 \mathrm{~h}$. Although we have no direct evidence to link this secondary increase in ATP levels to the onset of apoptosis, the ATP content in these cells may have been adequate for the death program to switch to apoptosis, which is an energy-dependent process $(13,14)$. The temporary recovery of ATP could also in part be ascribed to proteolytic inactivation of the ATP-consuming enzyme PARP, which is an early commitment step of apoptosis (33). By $24 \mathrm{~h}$, both the uptake of ${ }^{14} \mathrm{C}$-adenine and the ATP concentration had again declined to 61 and $36 \%$ of control values, respectively. At the time of this delayed ATP depletion, apoptotic cell death was detected by ISEL staining and DNA electrophoresis. This is in accordance with the study of Mailly et al. (12) in which a brief exposure to $200 \mu \mathrm{M} \mathrm{H}_{2} \mathrm{O}_{2}$ induced a decrease in neuronal ATP contents associated with increased apoptosis at $24 \mathrm{~h}$.

ATP depletion may be caused by decreased synthesis, increased utilization or catabolism, or efflux out of the cells. Oxidant exposure results in rapid activation of PARP, which is followed by depletion of cellular NAD and ATP, catabolism of ANs, and decrease in EC (34). This is a likely sequence of events in our experiments. Acute oxidant exposure may also increase cellular permeability and leakage of nucleotides (35), but this only occurred at the highest $\mathrm{H}_{2} \mathrm{O}_{2}$ concentration used. During the secondary energy failure there was no significant increase in nucleotides recovered in the medium, indicative of cell membrane damage. Thus it seems possible that the secondary ATP depletion was caused by decreased synthesis. Decreased ATP synthesis, in the face of functioning adenylate kinase in the cytoplasm, would be compatible with the observation that the EC remained normal in the secondary stage of energy failure. The potential causes for decreased ATP synthesis are lack of the cosubstrate, 5-phosphoribosyl-1pyrophosphate, for adenine salvage, or mitochondrial dysfunction, which has been shown to be associated with neuronal apoptosis induced by oxidants (29).

In addition to oxidant damage, the delayed phase of selective neuronal death after hypoxia-ischemia has been ascribed to induction of nitric oxide synthase, or activation of microglia, both of which have been shown to occur after a hypoxic insult in the CNS $(9,36)$. Transient exposure to $\mathrm{H}_{2} \mathrm{O}_{2}$ has also been shown to lead to accumulation of extracellular glutamate and delayed $N$-methyl-D-aspartate receptor activation (12). In our model, the roles of glutamate or activation of different forms of nitric oxide synthase have not yet been investigated.

Documentation of metabolic alterations by nuclear magnetic resonance spectroscopy gives a composite picture of events in the whole brain, but does not allow conclusions regarding different areas of the brain, or changes in neurons in comparison with other cell types. The present model aims at focusing the studies on the metabolic responses of neurons, although the possible presence of a small percentage of other cell types precludes definitive conclusions. However, the method of prelabeling the cells with a high-energy nucleotide precursor is a sensitive tool for exploring the acute and delayed effects of different exposures on cellular energy metabolism in vitro. The results have, of course, limited analogy to the complex interactions occurring in the CNS during ischemia-reperfusion. This model may prove useful for further investigating the roles played by PARP activation or inactivation, inducible nitric oxide synthase induction, or modifications caused by neuronalglial interactions. It also allows exploration of the possibilities of preventing the secondary deterioration of neuronal energy metabolism after an oxidative insult. 
Acknowledgments. We thank Sari Lindén and Ritva Löfman for skillful technical assistance, and Prof. Heikki Rauvala and Dr. Sami Kaukinen, University of Helsinki, for help in setting up neuronal cultures.

\section{REFERENCES}

1. Lorek A, Takei Y, Cady EB, Wyatt JS, Penrice J, Edwards AD, Peebles D, Wylezinska M, Owen-Reece H, Kirkbride V 1994 Delayed ("secondary") cerebral energy failure after acute hypoxia-ischemia in the newborn piglet: continuous 48-hour studies by phosphorus magnetic resonance spectroscopy. Pediatr Res 36:699-706

2. Penrice J, Lorek A, Cady EB, Amess PN, Wylezinska M, Cooper CE, D'Souza P, Brown GC, Kirkbride V, Edwards AD, Wyatt JS, Reynolds EO 1997 Proton magnetic resonance spectroscopy of the brain during acute hypoxia-ischemia and delayed cerebral energy failure in the newborn piglet. Pediatr Res 41:795-802

3. Hope PL, Costello AM, Cady EB, Delpy DT, Tofts PS, Chu A, Hamilton PA, Reynolds EO, Wilkie DR 1984 Cerebral energy metabolism studied with phosphorus NMR spectroscopy in normal and birth-asphyxiated infants. Lancet 2:366-370

4. Azzopardi D, Wyatt JS, Cady EB, Delpy DT, Baudin J, Stewart AL, Hope PL, Hamilton PA, Reynolds EO 1989 Prognosis of newborn infants with hypoxicischemic brain injury assessed by phosphorus magnetic resonance spectroscopy. Pediatr Res 25:445-451

5. Roth SC, Edwards AD, Cady EB, Delpy DT, Wyatt JS, Azzopardi D, Baudin J, Townsend J, Stewart AL, Reynolds EO 1992 Relation between cerebral oxidative metabolism following birth asphyxia, and neurodevelopmental outcome and brain growth at one. Dev Med Child Neurol 34:285-295

6. Blumberg RM, Cady EB, Wigglesworth JS, McKenzie JE, Edwards AD 1997 Relation between delayed impairment of cerebral energy metabolism and infarction following transient focal hypoxia-ischaemia in the developing brain. Exp Brain Res 113:130-137

7. Marks KA, Mallard EC, Roberts I, Williams CE, Sirimanne ES, Johnston B, Gluckman PD, Edwards AD 1996 Delayed vasodilation and altered oxygenation after cerebral ischemia in fetal sheep. Pediatr Res 39:48-54

8. Mehmet H, Yue X, Squier MV, Lorek A, Cady E, Penrice J, Sarraf C, Wylezinska M, Kirkbride V, Cooper C 1994 Increased apoptosis in the cingulate sulcus of newborn piglets following transient hypoxia-ischaemia is related to the degree of high energy phosphate depletion during the insult. Neurosci Lett 181:121-125

9. Beilharz EJ, Williams CE, Dragunow M, Sirimanne ES, Gluckman PD 1995 Mechanisms of delayed cell death following hypoxic-ischemic injury in the immature rat: evidence for apoptosis during selective neuronal loss. Brain Res Mol Brain Res 29:1-14

10. Fellman V, Raivio KO 1997 Reperfusion injury as the mechanism of brain damage after perinatal asphyxia. Pediatr Res 41:599-606

11. Whittemore ER, Loo DT, Watt JA, Cotman CW 1995 A detailed analysis of hydrogen peroxide-induced cell death in primary neuronal culture. Neuroscience 67:921-932

12. Mailly F, Marin P, Israel M, Glowinski J, Premont J 1999 Increase in external glutamate and NMDA receptor activation contribute to $\mathrm{H}_{2} \mathrm{O}_{2}$-induced neuronal apoptosis. J Neurochem 73:1181-1188

13. Eguchi Y, Shimizu S, Tsujimoto Y 1997 Intracellular ATP levels determine cell death fate by apoptosis or necrosis. Cancer Res 57:1835-1840

14. Leist M, Single B, Castoldi AF, Kuhnle S, Nicotera P 1997 Intracellular adenosine triphosphate (ATP) concentration: a switch in the decision between apoptosis and necrosis. J Exp Med 185:1481-1486

15. Lelli Jr JL, Becks LL, Dabrowska MI, Hinshaw DB 1998 ATP converts necrosis to apoptosis in oxidant-injured endothelial cells. Free Radic Biol Med 25:694-702

16. Volbracht C, Leist M, Nicotera P 1999 ATP controls neuronal apoptosis triggered by microtubule breakdown or potassium deprivation. Mol Med 5:477-489

17. Rauvala H, Merenmies J, Pihlaskari R, Korkolainen M, Huhtala ML, Panula P 1988 The adhesive and neurite-promoting molecule p30: analysis of the amino-terminal sequence and production of antipeptide antibodies that detect $\mathrm{p} 30$ at the surface of neuroblastoma cells and of brain neurons. J Cell Biol 107:2293-2305

18. Aalto TK, Raivio KO 1990 Adenine nucleotide depletion from endothelial cells exposed to xanthine oxidase. Am J Physiol 259:C883-C888

19. Atkinson DE 1968 The energy charge of the adenylate pool as a regulatory parameter: interaction with feedback modifiers. Biochemistry 7:4030-4034

20. Stocchi V, Cucchiarini L, Canestrari F, Piacentini MP, Fornaini G 1987 A very fast ion-pair reversed-phase HPLC method for the separation of the most significant nucleotides and their degradation products in human red blood cells. Anal Biochem 167:181-190

21. Armstead WM, Mirro R, Busija DW, Leffler CW 1988 Postischemic generation of superoxide anion by newborn pig brain. Am J Physiol 255:H401-H403

22. Bågenholm R, Nilsson UA, Kjellmer I 1997 Formation of free radicals in hypoxic ischemic brain damage in the neonatal rat, assessed by an endogenous spin trap and lipid peroxidation. Brain Res 773:132-138

23. Bågenholm R, Nilsson UA, Wallin Götborg C, Kjellmer I 1998 Free radicals are formed in the brain of fetal sheep during reperfusion after cerebral ischemia. Pediatr Res 43:271-275

24. Hasegawa K, Yoshioka H, Sawada T, Nishikawa H 1993 Direct measurement of free radicals in the neonatal mouse brain subjected to hypoxia: an electron spin resonance spectroscopy study. Brain Res 607:161-166

25. Phillis JW, Sen S 1993 Oxypurinol attenuates hydroxyl radical production during ischemia/reperfusion injury of the rat cerebral cortex: an ESR study. Brain Res 628:309-312

26. Zini I, Tomasi A, Grimaldi R, Vannini V, Agnati LF 1992 Detection of free radicals during brain ischemia and reperfusion by spin trapping and microdialysis. Neurosci Lett 138:279-282

27. Palmer C 1995 Hypoxic-ischemic encephalopathy: therapeutic approaches against microvascular injury, and role of neutrophils, PAF, and free radicals. Clin Perinatol 22:481-517

28. Chan PH, Kawase M, Murakami K, Chen SF, Li Y, Calagui B, Reola L, Carlson E, Epstein CJ 1998 Overexpression of SOD1 in transgenic rats protects vulnerable neurons against ischemic damage after global cerebral ischemia and reperfusion. J Neurosci 18:8292-8299

29. Keller JN, Kindy MS, Holtsberg FW, St Clair DK, Yen HC, Germeyer A, Steiner SM, Bruce-Keller AJ, Hutchins JB, Mattson MP 1998 Mitochondrial manganese superoxide dismutase prevents neural apoptosis and reduces ischemic brain injury: suppression of peroxynitrite production, lipid peroxidation, and mitochondrial dysfunction. J Neurosci 18:687-697

30. Hyslop PA, Zhang Z, Pearson DV, Phebus LA 1995 Measurement of striatal $\mathrm{H}_{2} \mathrm{O}_{2}$ by microdialysis following global forebrain ischemia and reperfusion in the rat: correlation with the cytotoxic potential of $\mathrm{H}_{2} \mathrm{O}_{2}$ in vitro. Brain Res 671:181-186

31. Aito H, Aalto TK, Raivio KO 1999 Correlation of oxidant-induced acute ATP depletion with delayed cell death in human neuroblastoma cells. Am J Physiol 277:C878-C883

32. Halliwell B, Gutteridge JMC 1989 Free Radicals in Biology and Medicine. Clarendon Press, Oxford, UK, pp 96-98

33. Lazebnik YA, Kaufmann SH, Desnoyers S, Poirier GG, Earnshaw WC 1994 Cleavage of poly(ADP-ribose) polymerase by a proteinase with properties like ICE. Nature 371:346-347

34. Schraufstatter IU, Hinshaw DB, Hyslop PA, Spragg RG, Cochrane CG 1986 Oxidant injury of cells: DNA strand-breaks activate polyadenosine diphosphate-ribose polymerase and lead to depletion of nicotinamide adenine dinucleotide. J Clin Invest 77:1312-1320

35. Aalto TK, Raivio KO 1993 Mechanisms of adenine nucleotide depletion from endothelial cells exposed to reactive oxygen metabolites. Free Radic Biol Med 14:177-183

36. Higuchi Y, Hattori H, Kume T, Tsuji M, Akaike A, Furusho K 1998 Increase in nitric oxide in the hypoxic-ischemic neonatal rat brain and suppression by 7-nitroindazole and aminoguanidine. Eur J Pharmacol 342:47-49 